\title{
THE ADVERTISING MARKET OF EUROPEAN UNION COUNTRIES - THE EVOLUTION IN RECENT YEARS
}

\author{
Laura Cătălina Țimiraş \\ Vasile Alecsandri University of Bacau \\ timiras.laura@ub.ro
}

\begin{abstract}
This paper seeks to highlight how the EU advertising market has evolved in recent years, as well as the link between the macroeconomic outcomes of the analyzed countries and the size of this market. According to the analyzed statistical data provided by Eurostat in recent years for which we have data, the advertising market (assessed by the Turnover or gross premiums written indicator) registered an upward trend in the EU, with the old EU members accounting about $90 \%$ of the total market, and the new member states just over 10\%. The number of market operators also increased, with about $75 \%$ of them operating at the level of the old EU members. The size of the advertising markets at the level of the analyzed countries is closely linked to the recorded macroeconomic outcomes, with a direct and strong link between the gross premiums written and the Gross domestic product. The link has been studied both across EU countries and separately for the two categories of old states (EU - 15) and new EU members.
\end{abstract}

\section{Keywords}

advertising market; turnover or gross premiums written; number of enterprises; gross domestic product; EU member states

\section{JEL Classification}

M31, M37, C10

\section{Highlights on the size of the global advertising market}

The emergence and development of advertising is strictly related to market developments, increased competition, increased and diversified consumer demands. Thus, in the context of general economic development, the advertising market has evolved to reach impressive dimensions. For example, in 2015, according to Statista, Inc. (2017), the global advertising market expressed in global advertising spending amounted 513.56 billion US Dollars, with an ascending trend, from 412.54 billion US Dollars in 2010 (which represents an annual average increase of about 4.5\%).

According to estimates for the coming years (eMarketer, 2016), the advertising market will continue the upward trend, with total advertising spending for 2020 being valued at over 720 billion US Dollars.

The largest advertising markets in the world, according to estimates for 2016 (Statista, Inc., 2017) are: United States, China, Japan, United Kingdom, Germany, Brazil, South Korea, France, Australia and Canada, global ad market being estimated at 537 billion US dollars. (Table 1) 
Table 1. World's largest advertising markets in 2016

\begin{tabular}{|l|c|}
\hline \multicolumn{1}{|c|}{ Country } & \multicolumn{1}{|c|}{$\begin{array}{c}\text { Advertising } \\
\text { expenditure for } \\
\text { 2016- estimated } \\
\text { values (billion U.S.) }\end{array}$} \\
\hline 1. United States & 190.84 \\
\hline 2. China & 80.24 \\
\hline 3. Japan & 37.68 \\
\hline 4. United Kingdom & 26.10 \\
\hline 5. Germany & 22.07 \\
\hline
\end{tabular}

\begin{tabular}{|l|c|}
\hline \multicolumn{1}{|c|}{ Country } & \multicolumn{1}{c|}{$\begin{array}{c}\text { Advertising } \\
\text { expenditure for } \\
\text { 2016- estimated } \\
\text { values (billion U.S.) }\end{array}$} \\
\hline 6. Brazil & 13.20 \\
\hline 7. South Korea & 11.56 \\
\hline 8. France & 11.46 \\
\hline 9. Australia & 11.06 \\
\hline 10. Canada & 9.05 \\
\hline
\end{tabular}

Source: Statista, Inc. (2017)

In fact, the global advertising market is highly concentrated; the top 10 countries in the world ( 3 of which belong to the EU), accounting for $77 \%$ of the world's advertising market, with the rest of the countries accounting for only $23 \%$. (Figure 1)

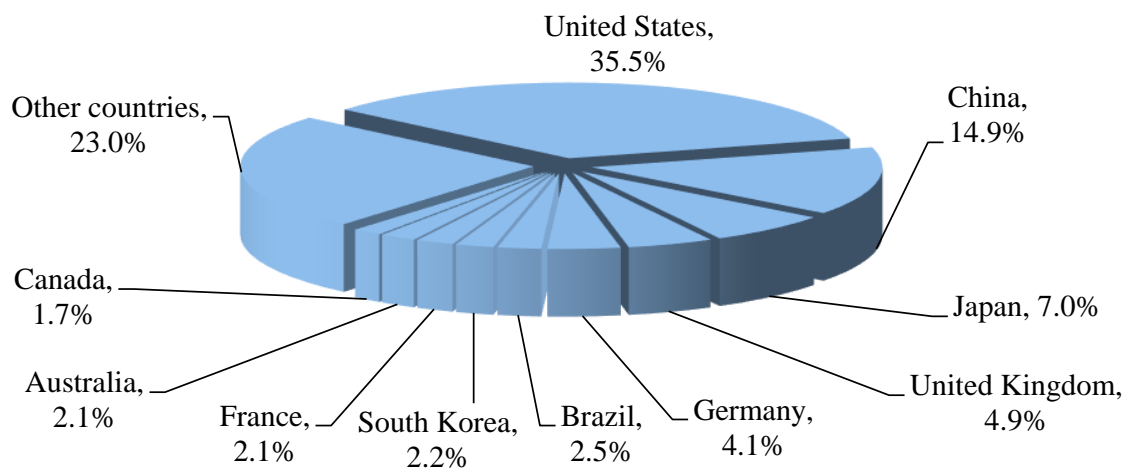

Figure 1. The structure of the global advertising market by country in 2016 ( $\%$ in global advertising spending - estimated values)

Source: personal processing from Statista, Inc. (2017)

Advertising expenditure are huge both at macroeconomic level (as shown in the table above) and at micro level for some of the big corporations. For example, in 2016, brands with the largest allocated advertising budgets in the world are shown in Table 2, their expenditure exceeding the value of 8 billion US dollars.

Table 2. Top of the largest advertising budgets in the world in 2016

\begin{tabular}{|l|c|}
\hline \multicolumn{1}{|c|}{ Brand } & $\begin{array}{c}\text { Advertising } \\
\text { budget for 2016 } \\
\text { (billion U.S.) }\end{array}$ \\
\hline Pampers & 8.3 \\
\hline Gillette & 8.3 \\
\hline L'Oreal & 8.2 \\
\hline Chevrolet & 5.1 \\
\hline Louis Vuitton & 4.4 \\
\hline Ford & 4.3 \\
\hline Coca-Cola & 4.0 \\
\hline Amazon & 3.8 \\
\hline Sony & 3.7 \\
\hline AT\&T & 3.6 \\
\hline
\end{tabular}

\begin{tabular}{|l|c|}
\hline \multicolumn{1}{|c|}{ Brand } & $\begin{array}{c}\text { Advertising } \\
\text { budget for 2016 } \\
\text { (billion U.S.) }\end{array}$ \\
\hline Lexus & 3.6 \\
\hline Toyota & 3.6 \\
\hline Samsung & 3.3 \\
\hline NIKE & 3.2 \\
\hline Google & 3.2 \\
\hline American Express & 3.1 \\
\hline T-Mobile & 2.9 \\
\hline Nissan & 2.8 \\
\hline Verizon & 2.7 \\
\hline Chase & 2.7 \\
\hline
\end{tabular}

Sursa: Wadlow, T. (2016), Top 20 companies with the biggest advertising budget, Business Review Europe 


\section{Methodological aspects}

The aim of this paper is to highlight the evolution of the advertising market in the EU countries in recent years and also to analyze the link between the macroeconomic outcomes and the size of this market. The study is based on official statistical data, using, for their analysis, indicators for time series and for studying the links between variables.

\section{The size and dynamics of the EU-wide advertising market}

For the assessment of the size and dynamics of the advertising market, was used data regarding turnover or gross premiums written as well as number of enterprises, respectively number of people employed in advertising. The analysis was based on the latest official data provided by Eurostat.

The EU-wide advertising market, expressed by the turnover or gross premiums written indicator, reached $€ 153$ billion in 2015 (up 6.4\% from 2011) of which almost $90 \%$ was held by the old states EU (EU-15), while the new member states (Bulgaria, Czech Republic, Romania, Slovenia, Slovakia, Poland, Hungary, Malta, Cyprus, Latvia, Lithuania, Croatia, Estonia) had just over 10\%. In 2014 there were almost 264.000 operators on this market (up by about 10\% over 2011) and more than 967.000 workers in the field. Of the total operators registered in 2014 , about $75 \%$ belonged to the old EU states (EU-15). (Table 3 and Figure 2)

\section{Table 3. Evolution of the EU-wide advertising market, respectively old and new member states in terms of turnover or gross premiums written, number of enterprises and number of persons employed}

\begin{tabular}{|c|c|c|c|c|c|c|c|c|c|}
\hline \multirow[b]{2}{*}{$\begin{array}{c}\text { Country } \\
\text { groups }\end{array}$} & \multicolumn{3}{|c|}{$\begin{array}{l}\text { Turnover or gross } \\
\text { premiums written } \\
\text { (millions of } \epsilon \text {.) }\end{array}$} & \multicolumn{3}{|c|}{$\begin{array}{c}\text { Number of enterprises } \\
\text { (enterprises) }\end{array}$} & \multicolumn{3}{|c|}{$\begin{array}{c}\text { Number of persons } \\
\text { employed } \\
\text { (persons) }\end{array}$} \\
\hline & 2011 & 2015 & 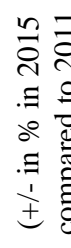 & 2011 & 2014 & 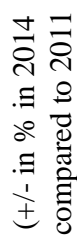 & 2011 & 2015 & 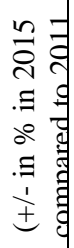 \\
\hline $\begin{array}{l}\text { The EU - } \\
15\end{array}$ & 128453.6 & 136871.9 & 6.6 & 177161 & 196158 & 10.7 & 771326 & 786534 & 2.0 \\
\hline $\begin{array}{l}\text { The new } \\
\text { member } \\
\text { states of } \\
\text { the UE }\end{array}$ & 15734.8 & 16609.9 & 5.6 & 63719 & 67708 & 6.3 & 169574 & 180638 & 6.5 \\
\hline $\begin{array}{l}\text { European } \\
\text { Union } \\
(28 \\
\text { countries) }\end{array}$ & 144188.4 & 153481.8 & 6.4 & 240880 & 263866 & 9.5 & 940900 & 967172 & 2.8 \\
\hline
\end{tabular}

Source: personal processing from Eurostat (2017)

By comparing the results obtained (turnover or gross premiums written) and the allocated resources (number of persons employed) there is a gap between the old and the new EU members. Thus, in the year 2015, $81.3 \%$ of the total number of employees in the EU advertising made $89.2 \%$ of the total turnover or gross premiums written, while $18.7 \%$ of them achieved only $10.8 \%$ of the total turnover or gross premiums written (indicators for new members). (Figure 2) 


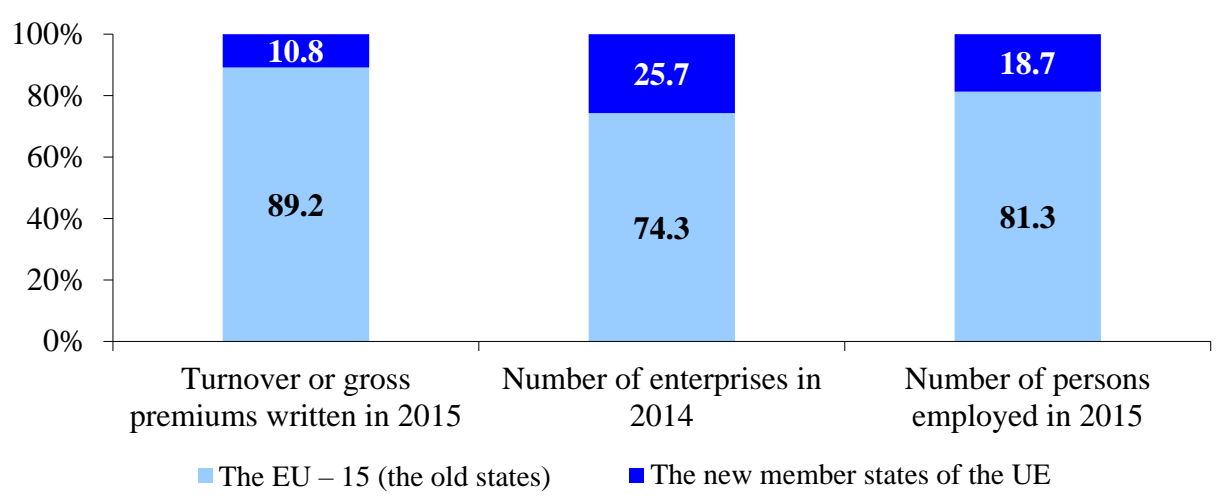

Figure 2. Structure of turnover or gross premiums written, number of enterprises and number of employed persons in advertising for old and new EU members $(\%)$

Source: personal processing from Eurostat (2017)

Referring to the size of the advertising market from the perspective of turnover or gross premiums written, by EU countries, the United Kingdom ranks first with a value of nearly 38 billion euros, followed by other old Member States, such as Germany, France, Spain, Italy etc., most of the new EU members being at the end of the ranking from this point of view. (Figure 3)

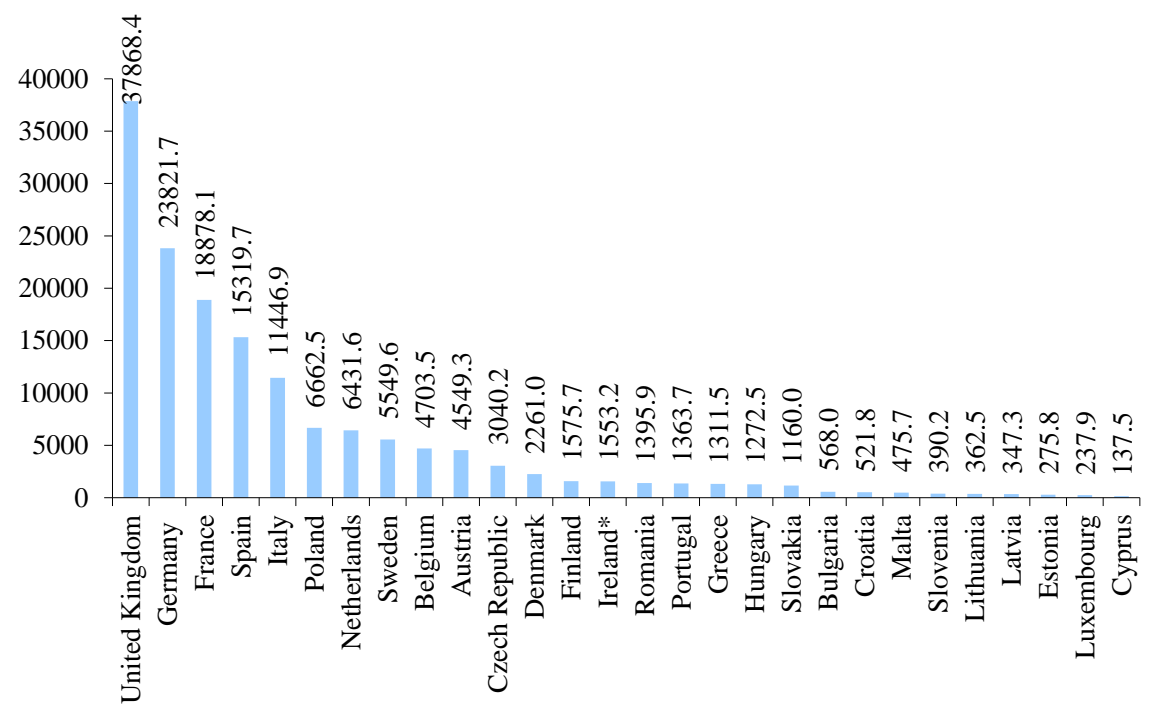

Figure 3. Turnover or gross premiums written made from advertising in the EU28 countries in 2015 (millions of $€$ )

Source: Eurostat (2017)

*2014 data

In dynamics, the period 2010-2015 was marked by different developments from one country to the other, with the most spectacular increases (more than 60\%) recorded in Estonia, Ireland (where, due to the lack of available official data, the dynamics was determined for the 2010-2014 period) and the United Kingdom. Greece and Portugal 
show the largest decreases in this market (over $40 \%$ for Greece and over $30 \%$ for Portugal). (Figure 4)

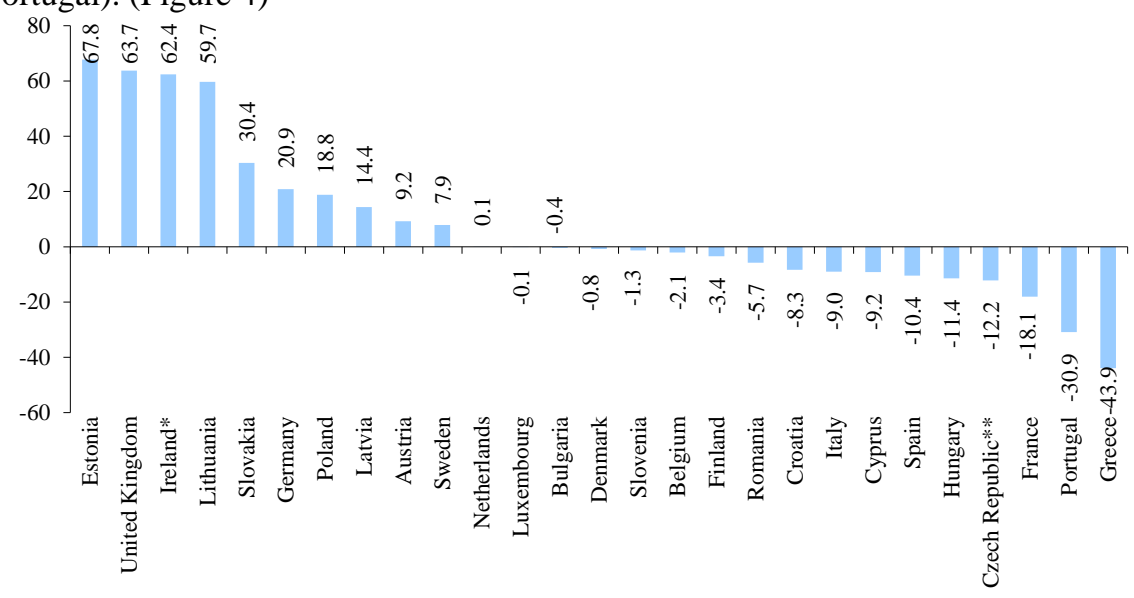

Figure 4. Percentage change in turnover or gross premiums written from advertising in EU-28 countries in 2015 compared to 2010 (+/- in \% as compared to 2010)

Source: personal processing from Eurostat (2017)

* 2014 compared to 2010

** 2015 compared to 2011

Note: no data for Malta

In terms of number of enterprises, the hierarchy of EU countries is different in 2014, the first places being occupied by Netherlands, followed by Germany, both with over 30.000 operators, Spain and France with more than 25.000 operators. (Figure 5)

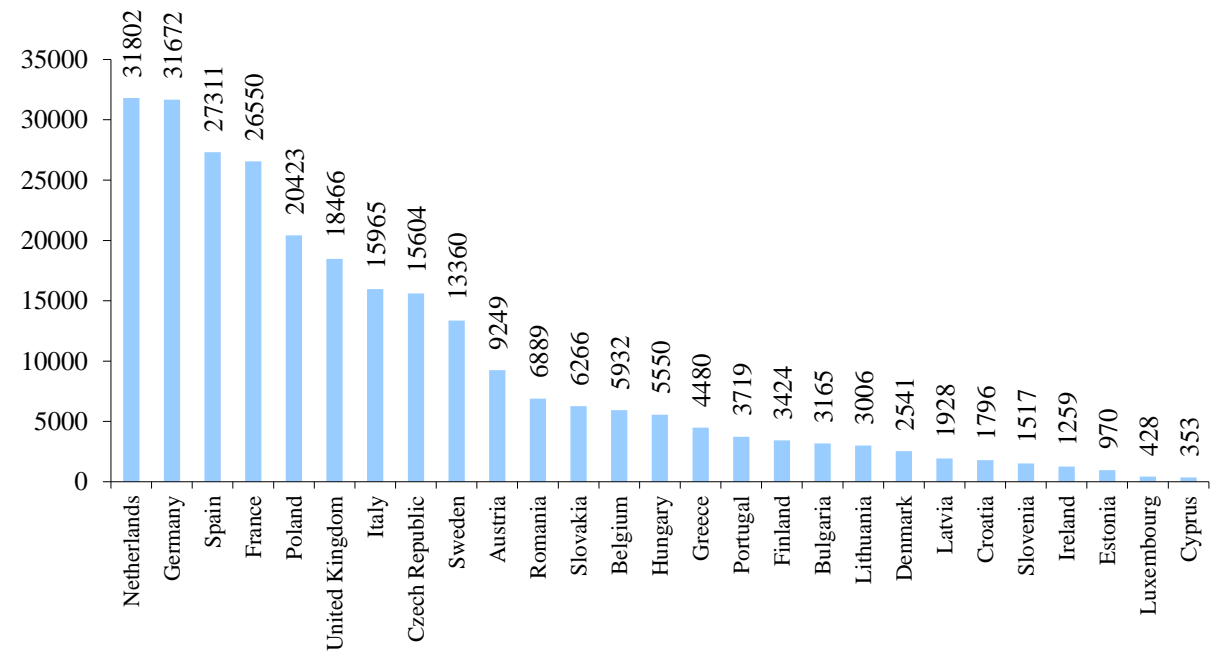

Figure 5. Number of enterprises in advertising in EU-28 countries in 2014

Source: Eurostat (2017)

Note: no data for Malta 
In most EU countries, there is an increase in the number of enterprises in advertising, with the largest increases being recorded in Lithuania and Ireland, while Greece and Portugal have also experienced the largest decreases. (Figure 6)

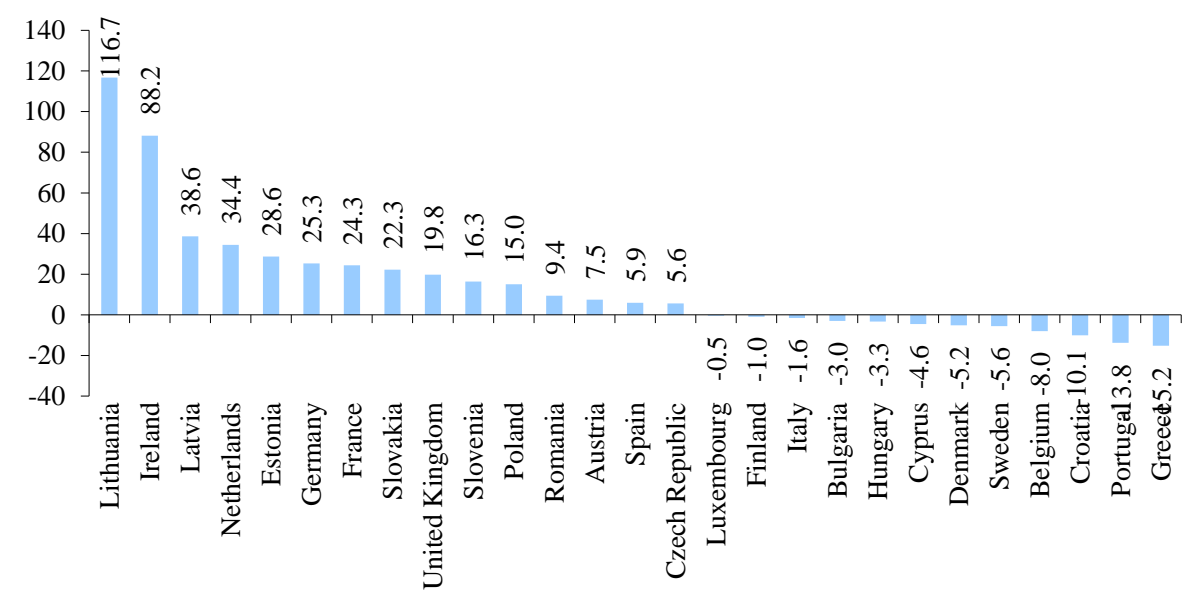

Figure 6. Percentage change in number of enterprises in advertising in EU-28 countries in 2014 compared to $2010(\%)$

Source: personal processing from Eurostat (2017)

Note: no data for Malta

The link between the macroeconomic outcomes and the size of the advertising market at EU level in 2015

There is a close link between the level of EU macroeconomic outcomes and the size of the advertising market. Thus, studying the correlation between the Gross domestic product and the gross premiums written from the advertising activity carried out by the $28 \mathrm{EU}$ states, we can see that there is a direct and strong link between them, the value of the correlation coefficient $r$ being 0.9367 .

Also, applying the significance test $t$ we obtain a calculated value $t=13.64$, which for a significance level $\alpha=0.0001$ and 26 degrees of freedom attests a significant correlation coefficient (the corresponding theoretical value $t$ is 4.587). (Figure 7 and Table 4)

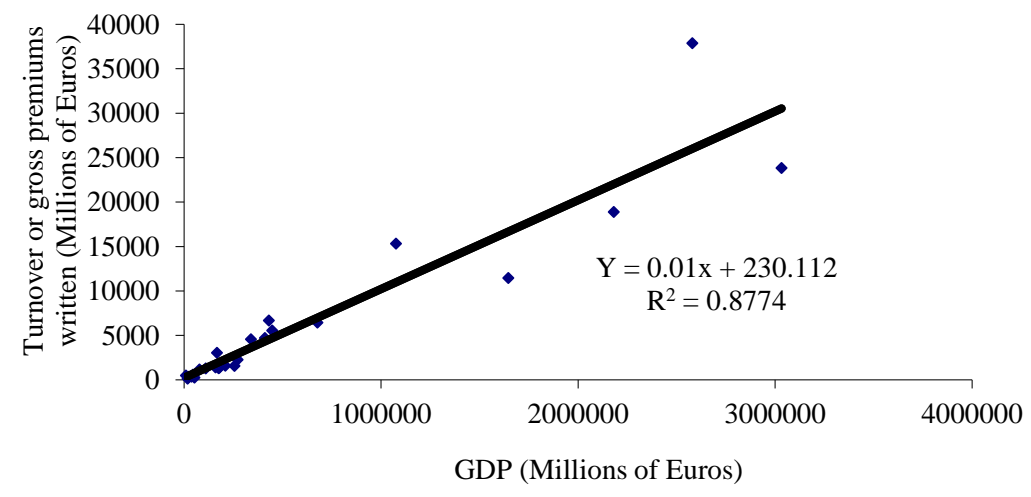

Figure 7. Link between Gross domestic product and Turnover or gross premium writing in advertising in EU-28 countries in 2015

Source: personal processing from Eurostat (2017)

Note: for Ireland has been used turnover or gross premiums written for 2014 
Similarly, studying the link between Gross domestic product and the gross premiums written from advertising activity by category of countries - the old and the new EU member states, we can see in both cases the manifestation of direct and strong links, for a level of significance with the level of 0.0001. In comparison, there is a stronger link between the two variables for the new EU member states (correlation coefficient $r$ calculated for the new EU member states with the value of 0.9791 compared to 0.9197 corresponding to the EU - 15 countries). (Figure 8 and Table 4)

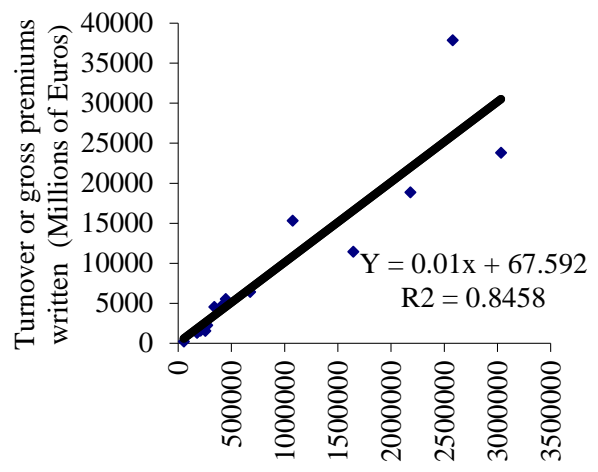

GDP (Millions of Euros)

EU - 15

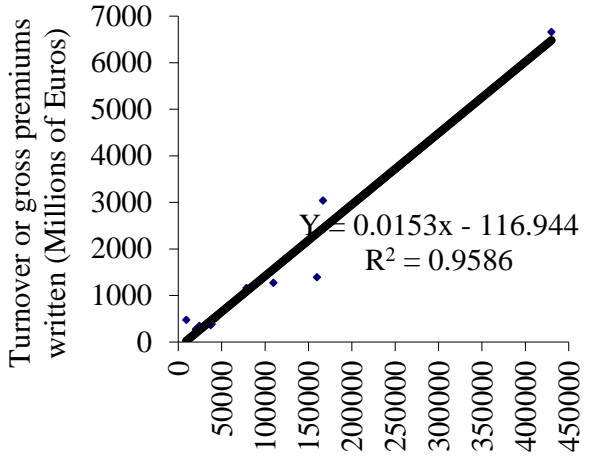

GDP (Millions of Euros)

New EU Member States

Figure 8. Relationship between Gross domestic product and turnover or Gross premiums written in advertising by categories of countries - old and new EU members in 2015

Source: personal processing from Eurostat (2017)

Note: for Ireland has been used turnover or gross premiums written for 2014

Table 4. Link between Gross domestic product and Turnover or gross premium writing made from advertising in EU countries in 2015

\begin{tabular}{|c|c|c|c|c|c|c|c|}
\hline Countries & 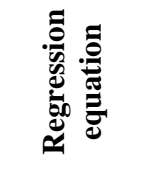 & 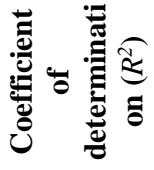 & 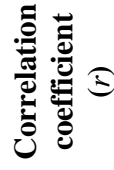 & 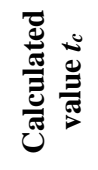 & 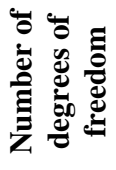 & 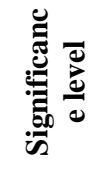 & 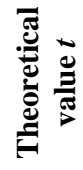 \\
\hline $\begin{array}{l}\text { European } \\
\text { Union (EU } \\
-28)\end{array}$ & $\begin{array}{l}Y=0.01 x \\
+230.112\end{array}$ & 0.8774 & 0.9367 & 13.641 & 26 & 0.0001 & 4.587 \\
\hline EU - 15 & $\begin{array}{l}Y=0.01 x \\
+67.592\end{array}$ & 0.8458 & 0.9197 & 8.444 & 13 & 0.0001 & 5.513 \\
\hline $\begin{array}{l}\text { New EU } \\
\text { member } \\
\text { states } \\
\end{array}$ & $\begin{array}{c}\mathrm{Y}= \\
0.0153 \mathrm{x}- \\
116.944 \\
\end{array}$ & 0.9586 & 0.9791 & 15.959 & 11 & 0.0001 & 5.921 \\
\hline
\end{tabular}

Source: personal processing from Eurostat (2017)

Note: for Ireland has been used turnover or gross premiums written for 2014

It is noted from the above table that the value of the regression coefficient has the same value at the level of equations determined for EU-28 and EU-15 (0.01) and was 0.0153 for the new EU member states. These values show that both at the EU-28 and at the EU-15 levels, on average, there is an increase of 1 billion Euro in Gross domestic 
product, related to an increase of 10 million Euro in Turnover or gross premium writing made from advertising; and, also, at the new EU member states level, related to an increase of 15,3 million Euro in Turnover or gross premium writing made from advertising.

\section{Conclusions}

This paper has attempted to capture both the evolution of the EU-wide advertising market beyond 2010 and the link between the macroeconomic outcomes of the member states and their level of economic development.

Thus, the EU advertising market accounted for over $€ 153$ billion in terms of turnover or gross premiums written in 2015, with almost $90 \%$ owned by the old EU countries. During the period 2011-2015, the indicator showed an upward trend, but this was also not the case for individual states (some of them declining). As far as the number of enterprisers in advertising is concerned, there were almost 244.000 organizations in the community space in 2014 , of which almost $75 \%$ belonged to the old member states.

There is a close link to the level of community space between the macroeconomic outcomes such as the Gross domestic product and the size of the advertising market assessed based on the Turnover or gross premiums written indicator, with higher macroeconomic outcomes being associated with larger advertising markets.

\section{References}

Harja E., Țimiraş L.C. (2009), Metode statistice utilizate în cercetarea de marketing, Bacau, Editura Alma Mater

Nichifor, B. (2014), Global Advertising Market - The Dynamics Of The Last Decade, Studies and Scientific Researches - Economics Edition, No. 20, pp. 196-202, available at http://sceco.ub.ro/index.php/SCECO/issue/view/12

Sincich, T. (1989), Business Statistics by Example. Third Edition, Dellen Publishing Company

Wadlow, T. (2016), Top 20 companies with the biggest advertising budget, Business Review Europe, available at http://www.businessrevieweurope.eu

Delloite (2016), The economic contribution of advertising in Europe. A report for the World Federation of Advertisers, available at https://www.iqads.ro/articol/37572/publicitatea-stimuleaza-crestereaeconomica-in-uniunea-europeana

eMarketer (2016), Worldwide Ad Spending: eMarketer's Updated Estimates and Forecast for 2015-2020, available at https://www.emarketer.com

Eurostat (2017), http://epp.eurostat.ec.europa.eu.

Statista Inc. (2017), https://www.statista.com 